Research Article

\title{
Universities as a fundamental component of innovation systems
}

\section{Las universidades como componente fundamental de los sistemas de innovación}

\section{Dr. Roberto Chang López}

Universidad Nacional Autónoma de Honduras; UPNFM; UTH; UNINTER; Universidad Internacional Iberoamericana

Correspondence: rchang@unah.edu.hn (iD) https://orcid.org/0000-0003-1244-2431

\begin{abstract}
This paper presents the innovation models from the Sabato model to the open innovation models and the triple or tetra helix models, which were potentiated with the OECD documents (1996) The knowledge-based economy and the development report World Development Report: Knowledge for Development 1998/1999 of the World Bank (1998) and relates to the role of the university in fostering innovation. Likewise, it presents reflection on the operation and development of innovation models in developed countries versus the Latin American region. Finally, it is identified that there are barriers or opportunities for the implementation of these models in Latin America due to the inconsistencies at the macro, meso and micro levels that must be overcome in order for these models to really work.
\end{abstract}

Keywords: innovation models, triple helix, tetra helix, university, Sabato triangle, open innovation.

Resumen: Este artículo presenta los modelos de innovación, desde el modelo de Sabato hasta los modelos de innovación abierta y los modelos de triple o tetra hélice, los cuales se potencializaron con los documentos la OCDE (1996) "The knowledge-based economy" y del informe de desarrollo mundial “World Development Report: Knowledge for Development 1998-1999" del Banco Mundial (1998). El artículo plantea la relación de estos modelos con el papel de la universidad en el fomento de la innovación. Asimismo, presenta una reflexión sobre el funcionamiento y desarrollo de los modelos de innovación en los países desarrollados en contraste con América Latina. Finalmente, se identifica que existen barreras y oportunidades para la implementación de estos modelos en América Latina debido a las incongruencias a nivel macro, meso y micro que deben ser superadas para que estos modelos puedan realmente funcionar.

Palabras clave: modelos de innovación, triple hélice, tetra hélice, universidad, triángulo de Sabato, innovación abierta. 


\section{Introduction}

World-class universities originate from the OECD document (1996) "The knowledge-based economy" and the "World Development Report: Knowledge for Development 1998-1999" of the World Bank (1998), which proposed four strategic and complementary dimensions to guide countries $^{1}$ to become knowledge-based economies ${ }^{2}$.

These 4 dimensions comprise an appropriate economic and institutional regime, a strong human being based on capital, a dynamic information infrastructure and an efficient national innovation system. Derived from the proposals of the OECD and the World Bank, the European Union launched from the beginning of the 2000s in the promotion of a "knowledge economy" in which the university is obliged to become a "competitive company to the service of economic growth" (Berr et al., 2017, p.1).

Salmi and Cai Liu (2011):

"Higher education is central to all four pillars of this framework, but its role is particularly crucial in support of building a strong human capital base and contributing to an efficient national innovation system. Higher education helps countries build globally competitive economies by developing a skilled, productive, and flexible labour force and by creating, applying, and spreading new ideas and technologies" (p. ix).

This knowledge-based economy is based on the university-company, which undermines university autonomy, mainly, on the freedom to investigate independently and without prejudice or assessment of private sector research agendas or criteria of editorial magazines.

Berr et al. (2017) say that "To achieve excellence - whose childish indicator is the Shanghai classification - it is convenient to mimic the unequal Anglo-Saxon model and renounce its own strengths" (p.1). However, this is not necessarily negative because with this proposal of the knowledge-based economy it is implicitly committing itself and routing the university to the economic development of the countries, leaving aside irrelevant issues for society that are sterile, which consume tax resources of the population without any economic and social remuneration.

Becoming a member of the exclusive group of world-class universities is not accomplished by self-declaration; but, the elite status until recently, involved a subjective rating, mainly for its reputation, for example, the Ivy League universities in the United States (USA), such as Harvard, Yale or Columbia; the universities of Oxford and Cambridge in the United Kingdom (United Kingdom); and the University of Tokyo, have traditionally been counted among the exclusive group of universities without quantitative measurement measures (Salmi \& Cai Liu, 2011).

In recent years, systematic ways of identifying and classifying world-class universities (IHEP, 2007) have appeared in tables and rankings. Although most of the best-known rankings seek to categorize universities within a country, there are also attempts to establish international rankings. The three largest international rankings are prepared by the Times Higher Education (THE) of the Shanghai Jiao Tong University (SJTU), QS World University Ranking and the Academic Ranking of World Universities (ARWU) (Salmi \& Cai Liu, 2011; García de Fanelli \& Pita Carranza, 2018).

\footnotetext{
${ }^{1}$ There are numerous government strategic fund programs to promote world-class universities in China, Japan, Russia, Korea, Germany, Saudi Arabia, Taiwan, among others with different financing schemes (See Yonezawa, 2019; Wang, Cheng; Cai Liu, 2012).

2 The European Union aims to "become the most competitive and dynamic knowledge-based economy in the world, capable of growing economically in a sustainable way with more and better jobs and greater social cohesion" (Lisbon Agreement: Lisbon European Council, March 23 and 24, 2000).
} 
Innovation models or systems in developed countries depend on the type of economy model adopted, for example, the open innovation system depends on industrial economic policies, while the triple or tetra helix innovation system is based on the model of knowledgebased economy. In the first, the company is the center, where innovation revolves, while in the second, innovation is coordinated by the university.

In this sense, there are numerous studies that address industrial parks such as Silicon Valley and Route 168 (Pique et al., 2018), among others, as incubators of innovations by business giants or studies that are aimed at analyzing the results of the production of invention patents and their relationship with the private sector, under the logic of commercialism and profitability and discuss What is the role of the government to improve the conditions of research, development and innovation as state financing programs to promote starups?

In Latin America, innovation models are incipient and many of the universities are nostalgic for the Cordoba Reform of 1918, in which the concepts of extension and connection emerge, which still appear in the higher education laws of Colombia, Ecuador Honduras, for example, but not that of innovation systems. Innovation systems in many Latin American countries are simulated in a government office with no link between the university and the business sector, so the open innovation models, the triple and tetra helix models represent a great development opportunity for the region.

\section{Development}

Numerous studies have been conducted in this regard with innovation systems, Leydesdorff et al. (2015) measured the synergy of Russia's regional, provincial and national innovation systems, because after the dissolution of the former Soviet Union, Russia's innovation systems were dispersed in a vast country of resources, mainly oil, where it is intended to move from a country dependent on resources (based on resources) to a country based on knowledge and coordinated more on a national level.

The synergy study by Leydesdorff et al. (2015) was based on the correlation analysis of the 3 dimensions of companies, university, and government in line with government programs of:

"The government actively encourages the development of science and technology parks, technology transfer offices, innovation centers, spin-off programs, etc. Technology incubation centers were set up within local universities, and their entrepreneurial capacity and ability to generate, manage, and promote start-ups was encouraged" (Leydesdorff et al., 2015, p.1229).

Strand et al. (2017) replicated the same study of Russian synergy in Norway's innovation system and one of their main conclusions is that counties with synergies dominated by technology and strong knowledge institutions have a higher level of international networks of co-inventors. The composition of innovation systems in Norway comprises networks of national and international co-inventors which promote national and international patents.

These same actions of the Russian and Norwegian government to promote science and technology have been taken by the UK government through the establishment of centers of innovation and technologies, which are denoted as intermediate centers between the university, industry and government, which have the structure to materialize the marketing research (Kerry \& Danson, 2016).

\section{Sabato model and other models of the XX and XXI century in Latin America}

According to Saltos et al. (2018) mention that, in Latin America in the first half of the last century, it can be identified that the development model of the Sabato Triangle is very similar to the triple helix model with the difference that the government was in charge of coordinating the university with the industry. At that time, Latin American governments actively participated in various industries because they owned these (state monopolies). 
However, due to the high politicization, lack of professionalized personnel and low investment in research and development, among other factors, this model failed, because it was oriented to grow without considering the market, because the government planned what, how and when about production.

Saltos et al., (2018) point out that:

"In accordance with the statements made by Sabato and Botana (1968), the UEG linkage models appear as a policy that allows Latin American countries to develop a technical and scientific capacity, based on identifying the actors that will make possible the insertion of science and technology in development, resulting from the coordination of the government, the productive structure and the scientific-technological infrastructure" (pp.129-130).

Another model presented by Saltos et al. (2018) is that of the innovation systems proposed in the national innovation systems with the purpose of promoting innovation, through dynamic interactions (supply of resources, knowledge, technology and demand for business and social solutions) between the different institutional agents through links, networks and information systems, incentives, continuous learning, use of new technologies, among others, in order to compete within the context of globalization. "These systems take into account the evolutionary and dynamic nature of innovation and, therefore, conceive it as cumulative, interactive and social, uncertain and institutional processes ..." (Saltos et al., 2018, p.130).

Saltos et al. (2018) also present the Management Model for linking university-businessstate through the use of ICTs, where all relationships are made through a website. The advantage of this model is to share fast and timely information among related institutions. This model is organized in 3 stages, the first is to identify the projects required by SMEs, second, the appointment of teachers and students participating in the execution of the project, and third, it involves verification and control together with company representatives.

In sum, all these models can work in different contexts, but they must have a macro regulatory framework that involves modifying the political constitutions of the countries, at the meso level, reforming industrial, economic, tax and higher education policies and at the microenterprise level and beneficiary families. All these modifications or reforms must be consistent with the political-economic model and with the idiosyncrasies of the population of each of the countries.

\section{Triple helix model and quadruple or tetra helix model}

Saltos et al. (2018) present the model of the triple helix and tetra helix by Henry Etzkowitz and Loet Leydesdorff (1995). Both in the triple helix and in the tetra helix, the link between university-business and government or civil society (Leydesdorff, 2012), the university is the center of research and development activities based on the needs and demands of the private sector and where the government's role is to manage public policies that stimulate the interactions of the university and the productive sector to promote economic development.

There are 3 derivations of this model and it is triple helix I (the government is coordinator of the link (Sabato \& Botana, 1968), II (the institutional autonomy of each actor is respected) and III (the university is the generating center of the investigation).

A common denominator between the triple helix model and the tetra helix is that universities must have "... an open disposition to the diagnosis and evaluation of third parties, and makes transparency and collaboration the central values with which to identify the way in which he decides to responsibly assume his commitment to society" (Saltos, et al., 2018, p.133). This generates sub-governance with respect to each business or social extension project of each university and sector involved.

The difference between the triple helix and the tetra helix model is that the latter considers the participation of civil society as a protagonist in development processes (Chang-Castillo, 2010). Likewise, both development models have drawbacks and complexities in their 
implementation in any country, according to Soto Vázquez (2006) this may be due to the fact that university economic and academic legislation, as well as national culture, do not allow these new relationships of co-responsibility and Commitments between the private sector and universities create synergies.

These drawbacks or complexities may be the product of the perception of these new relationships as threats to university governance and autonomy, on the one hand, and, on the other hand, to the institutional weakening of the university, as an institution subject to the interests of others actors in society and with a lack of academic independence to help solve economic and social problems (Saltos et al., 2018).

Both models are based on a knowledge-based society, which draws attention to the emerging coordination mechanisms of organized knowledge production in a knowledge-based economy (Leydesdorff, 2006; Leydesdorff, 2012; Whitley, 1999; Leydesdorff \& Ivanova, 2016). In a knowledge-based economy, the production of knowledge is the third coordination mechanism between markets and political institutions.

"However, the generation of wealth from knowledge or knowledge from wealth requires knowledge-based mediation by management or intervention by government to change the institutional conditions" (Leydesdorff \& Ivanova, 2016, p.2; Freeman \& Perez, 1988). Hancok (2019) states "Perhaps the most significant implication of the knowledge economy therefore is the expectation that the boundaries between the university, government, and industry will erode" (p.35).

\section{Open Innovation Models}

The open innovation (IO) model is based and developed based on an economic or industrial policy. The industrial economy takes for granted that markets and political institutions are the two most relevant mechanisms of coordination and selection (Leydesdorff \& Ivanova, 2016).

Leydesdorff and Ivanova (2016) explain that the open innovation (OI) model in the company occupies a central place in the innovation process, while the triple helix model can be multi-center, in which companies, universities and for example, regional governments can take leadership roles in innovation ecosystems. Technology transfer plays a transversal role in each moment of time, through the dynamics of feedback loops, which are the product of constant interactions between actors on knowledge, demand and technology.

These feedback cycles or loops can be turned into breakthroughs that drive innovation ecosystems toward self-organization and self-catalytic generation of new options, leaving behind knowledge and old technologies, creating new customer markets (demands) through that they call as generation of options or alternatives.

Torres and Frost-González (2015) point out that the open innovation model highlights the importance of external knowledge to increase the innovative capacity of companies "in any of its different activities -product, process, marketing, organizational, social, among others- and levels - radical or incremental - as well as the possibilities of using their own and external marketing channels to bring their innovations to the market" (p.253). This emphasis on external knowledge is in contrast to the traditional R\&D departments, where all ideas were generated from the internal members of the organization.

One way to evaluate an innovation system according to Leydesdorff and Ivanova (2016) is based on the options it generates, a system without enough options is a blocked system. "The generation of redundancy - the Triple Helix indicator - can be used as a measure of unrealized but technologically feasible options given a historical configuration" (Leydesdorff \& Ivanova, 2016, p.1). This generation of redundancy is derived from the same information from the different perspectives of the different coordination mechanisms (markets, policies, knowledge). For these authors, "Increased redundancy not only stimulates innovation in an ecosystem by 
reducing the prevailing uncertainty; it also enhances the synergy in and innovativeness of an innovation system" (Leydesdorff \& Ivanova, 2016, p.1).

\section{Comparison of innovation models}

The Open Innovation model (Chesbrough, 2003) and the Triple Helix of the industrygovernment university (Etzkowitz \& Leydesdorff, 1995; Etzkowitz \& Leydesdorff, 2000; Leydesdorff \& Ivanova, 2016) seem that at first glance they have much in common in terms of its established objectives to bring industrial innovation closer to public R\&D (Leydesdorff \& Ivanova, 2016). But, these models differ in terms of their discipline, political antecedents and objectives, for example, Chesbrough (2003) formulated open innovation in a paradigm that assumes that companies can and should use external ideas, as well as internal and external ideas to the market, as companies seek to advance their technology. Meanwhile, the triple helix model focuses on the knowledge infrastructure of innovations from the university-industrygovernment relationship.

Because these two innovation models (open innovation model and the triple helix model) are far from linear models, due to their interactions and complexity, it is important to consider that in these models there can be no expectations that the 3 interactions or agents are in permanent balance (Leydesdorff, 1994; Leydesdorff \& Van den Besselaar, 1998; Leydesdorff \& Ivanova, 2016). Therefore, this condition of "disturbance of equilibrations tends to become structural in a knowledge-based economy. Therefore, economic assumptions have to be reformulated in this neo-evolutionary framework (Andersen, 1994)." (Leydesdorff \& Ivanova, 2016, p.3)

The generation of options is considered in both innovation models, much more important than historical achievements ("best practices") for the long-term viability of knowledge-based innovation systems. In this sense, best practices, the standardization of production or quality systems and benchmarking are the main limitations for innovation models, which are not epistemologically based on science and its application in the contextual phenomenon for generate new knowledge, but in the pure technique to control results (Leydesdorff \& Ivanova, 2016).

In the triple helix model, the public and the private, derived from the interactions of the university-business-government link, are reconstructed in a knowledge-based economy, through conditions facilitated by the government to promote innovation, for example, in terms of intellectual property rights, the Bayh-Dole law, "brings industrial aspiration as a third mission to the core of institutional agreements between federal or national governments and national or state universities." (Leydesdorff \& Ivanova, 2016, p.3) to allow in 1980 the financing of universities through patents based on federal funds (Benneworth, 2018).

For Kerry and Danson (2016) "there is a considerable theoretical overlap between literature on the Triple Helix model/systems and literature on open innovation" (p.67) because intermediate organizations as brokers in the Triple Helix model, forge relationships between universities, industry and government through engagement and collaboration schemes, which is synonymous with the open innovation model (Kerry \& Danson, 2016; Nakwa \& Zawdie, 2012).

Kerry and Danson (2016) argue that the research flow of regional innovation systems and Triple Helix transmission is based on open innovation thinking, that these concepts need to be cohesively explored. Also, they say that in the current literature there is a lack of discussion about how these concepts are theoretically related and intertwined. In addition, open innovation, the Triple Helix and regional innovation systems play a combined and equal role in driving economic growth, therefore it needs further consideration.

In this sense, under the triple helix model, both the public and private sectors are favored and the effects on society have a broader scope, while the open innovation model is more 
focused on the firm or company. Therefore, the open innovation models have a reductionist approach, while the triple helix model is a broader approach.

\section{Conclusions}

Taking Latin American studies of innovation systems are rhetorical and non-prescriptive and not at all propositional, they address historical problems and it is not clear the position of the type of economies that countries should follow, such as, for example, a knowledge-based economy or an economy based on industrial policy. However, it is curious that there are still government offices or agencies in charge of promoting innovation in Latin American countries, which are isolated from the university and the needs of the business sector, whose current performance is worse than the Sabato Triangle, which dates from the first half of the 20th century.

University governance in developed countries focuses on educational quality, research, development, and innovation, while that of under-administered countries in their studies seems to focus on understanding how university social cohesion affects governability? What is the role and impact of university extension and university social responsibility for the development of societies, but as a non-formal academic extension program for communities and not from the perspective of development and reciprocal commitments with the sector productive and social as those presented in the innovation models?

The viability, feasibility and legitimization of governance at the macro level of innovation models are subject to the approval of public policy reforms with a greater scope than the university ones expressed as a sincere desire to contribute to economic development, for example, a vision of country that expresses an industrial policy (open innovation models) or promotes a knowledge-based society (triple helix), as established by the OECD recommendations (1996) "The knowledge-based economy" and the "World development report: knowledge for development 1998-1999" of the World Bank (1998).

At the meso level, deep reforms will be needed in the higher education system and in the statutes of the universities, reorienting their main tasks, autonomies, university governance and even their financing models. This type of link UEG needs the commitment and legitimacy of all actors, State, University, private company and society, because spontaneous relationships, without defined directions, are not sustainable.

At the micro level, universities should strategically search for private sector companies with whom to work in order to create and maintain win-win relationships, generating new knowledge for the development of communities, but depending on the type of economy in which it is developed, whether these are based on knowledge or under industrial policies and with the collaboration of governments in matters of public policies that do not hinder innovations.

\section{References}

Benneworth, P. (2018). Definitions, approaches and challenges to community engagement. In: P. Benneworth, B. Ćulum, T. Farnell, F. Kaiser, M. Seeber, N. Šćukanec, H. Vossensteyn \& D. Westerheijden (eds.), Mapping and Critical Synthesis of Current State-of-the-Art on Community Engagement in Higher Education (pp.16-40, Ch. 1). Zagreb: Institute for the Development of Education.

Berr, E., Moulin, L. \& Médor, D. (2017). La mercantilización de la universidad francesa. Diálogos sobre educación. Temas actuales en investigación educativa, 8(14), 1-6.

Chang-Castillo, H. G. (2010). El modelo de la triple hélice como un medio para la vinculación entre universidad y empresa. Revista Nacional de Administración. Escuela de Ciencias de Administración, Costa Rica, $1(10), 85-94$ 
Chesbrough, H. W. (2003). Open Innovation: The new imperative for creating and profiting from technology. Boston: Harvard Business School Press.

Da Wan, C., Lee, M. N. \& Loke, H. Y. (eds.). (2019). The Governance and Management of Universities in Asia: Global Influences and Local Responses. New York: Routledge.

Etzkowitz, H. \& Leydesdorff, L. (1995). The Triple Helix---University-Industry-Government Relations: A Laboratory for Knowledge-Based Economic Development. EASST Review, 14(1), 14-19.

Etzkowitz, H. \& Leydesdorff, L. (2000). The Dynamics of Innovation: From National Systems and "Mode 2 " to a Triple Helix of University-Industry-Government Relations. Research Policy, 29(2), 109-123. DOI: https://doi.org/10.1016/S0048-7333(99)00055-4

European Council. (2000). Lisbon agreement: Lisbon European Council 23 and 24 March. European Parliament. Available at: https://www.europarl.europa.eu/summits/lis1_es.htm

García de Fanelli, A. \& Pita Carranza, M. (2018). Los rankings y sus usos en la gobernanza universitaria. CTS: Revista iberoamericana de ciencia, tecnología y sociedad, 13(37), 96-113.

Hancock, S. (2019). A future in the knowledge economy? Analysing the career strategies of doctoral scientists through the principles of game theory. Higher Education, 78(1), 33-49. DOI: https://doi.org/10.1007/s10734-018-0329-z

Kerry, C. \& Danson, M. (2016). Open innovation, Triple Helix and regional innovation systems: Exploring CATAPULT Centres in the UK. Industry and Higher Education, 30(1), 67-78. DOI: https://doi.org/10.5367/ihe.2016.0292

Leydesdorff, L. (1994). Epilogue. In: L. Leydesdorff \& P. A. A. van den Besselaar (eds.), Evolutionary Economics and Chaos Theory: New directions for technology studies (pp. 180-192). London/New York: Pinter.

Leydesdorff, L. (2006). The Knowledge-Based Economy: Modeled, Measured, Simulated. Boca Raton: Universal Publishers.

Leydesdorff, L. (2012). The Triple Helix, Quadruple Helix ..., and an N-tuple of Helices: explanatory models for analyzing the knowledge-based economy. Journal of the Knowledge Economy, 3(1), 25-35. DOI: https://doi.org/10.1007/s13132-011-0049-4

Leydesdorff, L. \& Ivanova, I. (2016). “Open innovation" and "triple helix" models of innovation: can synergy in innovation systems be measured? Journal of Open Innovation: Technology, Market, and Complexity, 2(1), 11. DOI: https://doi.org/10.1186/s40852-016-0039-7

Leydesdorff, L. \& Van den Besselaar, P. (1998). Technological developments and factor substitution in a complex and dynamic system. Journal of Social and Evolutionary Systems, 21(2), 173-192. DOI: https://doi.org/10.1016/S1061-7361(00)80004-1

Leydesdorff, L., Perevodchikov, E. \& Uvarov, A. (2015). Measuring triple-helix synergy in the Russian innovation systems at regional, provincial, and national levels. Journal of the Association for Information Science and Technology, 66(6), 1229-1238. DOI: https://doi.org/10.1002/asi.23258

Nakwa, K. \& Zawdie, G. (2012). The role of innovation intermediaries in promoting the triple helix system in MNC-dominated industries in Thailand: the case of hard disk drive and automotive sectors. International Journal of Technology Management and Sustainable Development, 11(3), 265-283. DOI: https://doi.org/10.1386/tmsd.11.3.265_1

OECD. (1996). The Knowledge-Based Economy. Paris: OCDE.

Pique, J. M., Berbegal-Mirabent, J. \& Etzkowitz, H. (2018). Triple Helix and the evolution of ecosystems of innovation: the case of Silicon Valley. Triple Helix, 5(1), 1-21. DOI: https://doi.org/10.1186/s40604-018-0060-x 
Sabato, J. \& Botano, N. (1968). La ciencia y la tecnología en el desarrollo futuro en América Latina. Revista de la Integración, 1(3), 15-36.

Salmi, J. \& Cai Liu, N. (2011). Paths to a world-class university. In: N. C. Liu, Q. Wang \& Y. Cheng (eds.), Paths to a World-Class University Lessons from Practices and Experiences (pp. ix-xviii). Rotterdam: Sense Publishers.

Saltos, G., Odriozola, S. \& Ortiz, M. (2018). La vinculación universidad-empresa-gobierno: una visión histórica y conceptual. Revista ECA Sinergia, 9(2), 121-139.

Soto Vázquez, R. (2006). Vinculación Universidad-empresa-estado en la realidad actual de la industria farmacéutica mexicana. Edusfarm, revista d'educació superior en Farmàcia, 2, 19-20.

Strand, Ø., Ivanova, I. \& Leydesdorff, L. (2017). Decomposing the Triple-Helix synergy into the regional innovation systems of Norway: firm data and patent networks. Qual Quant 51, 963-988. DOI: https://doi.org/10.1007/s11135-016-0344-z

Torres, C. \& Frost-González, S. (2015). Innovación abierta en empresas colombianas: reto a superar. Revista Venezolana de Gerencia, 20(70), 252-267.

Wang, Q., Cheng, Y. \& Cai Liu, N. (2012). Building world-class universities: Different approaches to a shared goal. In: Q. H. Wang, Q. Wang \& N. C. Liu (eds.), Building world-class universities in China: Shanghai Jiao Tong university (pp. 1-10). Rotterdam: Brill Sense

Whitley, R. D. (1999). Divergent Capitalisms: The Social Structuring and Change of Business Systems. New York: Oxford University Press.

World Bank. (1998). World Development Report 1998-1999: Knowledge for Development. New York: Oxford University Press.

Yonezawa, A. (2019). Japan: World-Class Universities for Social Innovation. International Higher Education, (96), 21-23. DOI: https://doi.org/10.6017/ihe.2019.96.10779

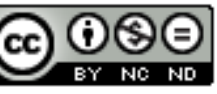

(C) Attribution-NonCommercial-NoDerivatives 4.0 International (CC BY-NC-ND 4.0) https://creativecommons.org/licenses/by-nc-nd/4.0/ 